students as socially mature personalities, develop their active civic position, ensure cooperation with other students at the all-Ukrainian level; participation of students in project activities that ensure upbringing of their civic qualities. The design methodology is based on the direct application of the acquired knowledge and skills in the practical activity of the student, therefore, he passes all forms of educational activity - lesson, extracurricular, outof-school and self-educational.

Key words citizenship education, forms and methods of citizenship education, student self-government, volunteer movement at school, children's and youth organizations, students' project activities.

УДК 378.937

\author{
Наталія Лавриченко \\ Глухівський національний педагогічний \\ університет імені Олександра Довженка \\ ORCID ID 0000-0003-0776-7362 \\ DOI 10.24139/2312-5993/2019.07/071-080
}

\title{
РОЗВИВАТИ МУЗИЧНУ ОБДАРОВАНІСТЬ
}

Феномен музичної обдарованості розглянуто в сукупності генетичних передумов, головних чинників розвитку, структурних складників та особливостей реалізації в життєвій практиці. Проаналізовано специфічні ознаки й характеристики музично обдарованої особистості, зокрема в контексті інших видів обдарованості, мультиобдарованості.

Ключові слова: обдарована дитина, музичні здібності, навчання, розвиток.

Постановка проблеми. Природу музичної обдарованості найчастіше розуміють як таку, що має генетичну зумовленість, а музичні здібності вважають природним даром. На підтвердження наводять приклади династій, яких порівняно більше серед музично обдарованих людей - Бахи, Вагнери, Моцарти, Ріхтери, Ростроповичі, Щендрини тощо. «Якщо й існує галузь людських досягнень, у якій важливо мати певні генетичні задатки, то це музика» - констатує винахідник множинного інтелекту Г. Гарднер (Гарднер, 2007, с. 164).

Разом із тим, чимало дослідників музичної обдарованості не тільки не заперечують, а навпаки, підкреслюють важливість навчання й виховання, цілеспрямованого формування необхідних для музики людських якостей і рис характеру, а також роль шансу, сприятливих умов і обставин. У реальному житті успадковані й набуті здібності, зокрема й музичні, настільки тісно переплетені, що їх складно диференціювати, тим паче ранжувати. Адже генотип як сукупність генетично зумовлених здібностей визначає музичну обдарованість здебільшого як потенційну, а от реальних обрисів вона набуває в процесі взаємодії індивіда з оточенням - соціальним, культурним, мистецьким. 
На загал у генотип, як сукупність природних задатків і схильностей, надалі вносить істотні корективи процес розвитку музично обдарованої особистості, зокрема умови його перебігу. У результаті формується фенотип чи то феномен музично обдарованої особистості з притаманним лише їй набором здібностей, здатностей, досягнень. Як зазначає Шутер-Дайсон, люди мають природжені здібності сприймати й творити музику, однак ці здібності $\epsilon$ різними, здібності можуть зазнавати обмежень або, навпаки, сприяння з боку середовища, власної мотивації, тому досягнуті результати виявляються різними (Shuter-Dyson, 1982, с. 393). Отже, не можна стверджувати, що наразі вчені мають погоджену думку щодо того, що $є$ вирішальним у проявленні й розквіті музичного таланту - спадковість, навчання, особистісні якості, середовище, шанс, чи все разом (Parncutt \& M cPherson, 2002, с. 8-9).

Аналіз актуальних досліджень. У пошуках універсальних основ музичного таланту дослідники приділяють значну увагу музикальності. Щоправда й тут немає однозначності: як у розумінні самого поняття «музикальність», так і взаємозв'язку між музикальністю і музичною обдарованістю. Найбільш радикальна позиція є такою: музикальність або $\epsilon$, або її немає, і тоді немає підстав говорити про музичну обдарованість. За іншого підходу значущість музикальності визнається, однак вона не ототожнюється з музичною обдарованістю цілковито. Безумовно, складно мислити музично обдаровану людину як не музикальну, з іншого боку, серед людей, які не належать до музичних талантів, можна знайти чимало осіб із виразною музикальністю, як виконавців, так і слухачів.

Відомий дослідник музичної обдарованості Б. М. Тєплов вважає, що музикальність $€$ компонентом музичної обдарованості, який абсолютно необхідний для всіх видів музичної діяльності. Головною ознакою музикальності вчений вважає здатність переживати, сприймати музику як втілення й вираження певного змісту (Теплов, 1947, с. 36). Разом із тим, Б. М.Тєплов наводить судження Г. Кеніга щодо того, що музикальність $€$ синтетичною якістю, яка виникає внаслідок поєднання наявних у індивіда музичних здібностей. Понад те, без конкретних здібностей поняття «музикальність» не має під собою жодної реальності, однак вона (музикальність) не є простою сумою музичних здібностей (Теплов, 1947, с. 40).

Для розкриття природи музичної обдарованості як складного поєднання здібностей дослідниця Джоан Хараутауніан запропонувала поняття метаперцепції. Під метаперцепцію вона розуміє перцептивний і когнітивний процеси у їх взаємодії, унаслідок чого музикант стає спроможним: а) сприймати звуки внутрішнім чуттям; б) запам'ятовувати звуки; в) маніпулювати звуками для досягнення більшої виразності, експресії; г) доносити креативну інтерпретацію звуків до інших людей (Haroutounian, 2000, с. 146). 
Мета статті - проаналізувати природу й динаміку розвитку музичної обдарованості, розкрити особливості педагогічної роботи з музично обдарованими дітьми. Для реалізації мети застосовано такі наукові методи: аналіз, синтез, узагальнення, конкретизація, систематизація.

Виклад основного матеріалу. Спроби вчених винайти необхідні й закономірні визначники музичної обдарованості важливі, однак, як на нашу думку, універсальна модель тут навряд чи ймовірна. Адже в кожному конкретному випадку музично обдарована особистість репрезентує унікальне поєднання здібностей, що проявляються й реалізуються в таких головних підвидах музичної діяльності, як творчість, виконавське мистецтво, сприйняття. Нижче наводимо перелік здібностей (див. табл. 1), які $€$ специфічними для музично обдарованої особистості, а їх варіативне поєднання й інтерактивне підсилення обумовлює самобутність таланту.

Таблиця 1

\section{Складники музичної обдарованості}

\begin{tabular}{|c|c|}
\hline $\begin{array}{c}\text { Вид музичної здібності } \\
\text { (здатності) }\end{array}$ & Характеристика \\
\hline Абсолютний слух & $\begin{array}{l}\text { Здатність розпізнавати звуки за їх висотою, точно вказувати } \\
\text { ноти («до», «ре», «мі» тощо), визначати висоту звуку без } \\
\text { попереднього тренування й співвіднесення } 3 \text { іншими } \\
\text { звуками, висота яких відома }\end{array}$ \\
\hline Гармонічний слух & $\begin{array}{l}\text { Здатність сприймати музику як багатоголосу і водночас } \\
\text { гармонійно структуровану, відрізняти злагоджене звучання } \\
\text { від незлагодженого, визначати співзвучність акордів (тони, } \\
\text { інтервали, співвідношення висоти звуків) }\end{array}$ \\
\hline Ритмічний слух & $\begin{array}{l}\text { Здатність активно (у русі) переживати музику, відчувати } \\
\text { ритм, темп, розміреність рухів, визначати співвідношення } \\
\text { між різними ритмічними одиницями, точно їх відтворювати }\end{array}$ \\
\hline Внутрішній слух & $\begin{array}{l}\text { Внутрішнє уявлення музичних тонів і їх співвідношень без } \\
\text { участі голосу, уміння на слух добирати мелодію, виконувати } \\
\text { музичні фрагменти без нот }\end{array}$ \\
\hline Мелодійний слух & $\begin{array}{l}\text { Здатність чути й розуміти будову мелодії - висоту звуків, } \\
\text { тембр, ритмічну організацію, протяжність звучання мелодії в } \\
\text { просторі й часі, міру завершеності (ладове відчуття) }\end{array}$ \\
\hline Музична пам'ять & $\begin{array}{l}\text { Здатність запам'ятовувати музичні тексти, інформацію, } \\
\text { необхідну для роботи з ними; спонтанно відтворювати } \\
\text { музичний твір через паузу, як коротку, так і довготривалу }\end{array}$ \\
\hline Музичне відчуття & $\begin{array}{l}\text { Емоційний відгук на музику, здатність емоційно виражати } \\
\text { себе в музиці, переживати музику як таку, що несе певний } \\
\text { зміст, ідею, отримувати натхнення від музики і бажання } \\
\text { самовдосконалюватися в ній }\end{array}$ \\
\hline Музичний інтелект & $\begin{array}{l}\text { Музичне мислення як аналітико-синтетична здатність може } \\
\text { проявлятися в багатьох видах діяльності, у множині ситуацій. } \\
\text { Завдяки специфічно організованій активності мозку людина } \\
\text { спроможна чути, відчувати, розуміти, створювати, } \\
\text { відтворювати, рефлексувати музику }\end{array}$ \\
\hline
\end{tabular}




\begin{tabular}{|l|l|}
\hline $\begin{array}{l}\text { Креативна } \\
\text { інтерпретація }\end{array}$ & $\begin{array}{l}\text { Здатність закласти в музичний твір власну концепцію його } \\
\text { розуміння, тлумачення; індивідуальний підхід до музики } \\
\text { (співака, музиканта, диригента, композитора); неповторний } \\
\text { «почерк»музикування, аранжування, співу; творча експресія }\end{array}$ \\
\hline $\begin{array}{l}\text { Музично-слухове } \\
\text { уялення }\end{array}$ & $\begin{array}{l}\text { Здатність до відтворення почутої мелодії з опертям на } \\
\text { музичну пам'ять, уявлення звуковисотних і ритмічних } \\
\text { співвідношень між звуками, репродуктивний компонент } \\
\text { музичного слуху (внутрішній слух) }\end{array}$ \\
\hline Музична дія, дійство & $\begin{array}{l}\text { Енергія цілеспрямованої музичної активності (репетиції, } \\
\text { виступи, концерти), музична творчість (написання музики, } \\
\text { креативна інтерпретація музичних творів), гра на музичних } \\
\text { інструментах, заняття вокалом тощо. у процесі різних видів } \\
\text { музичної діяльності відшліфовуються, удосконалюються } \\
\text { музичні здібності, формується здатність розпізнавати, } \\
\text { розуміти музичні стилі й техніки, витончується сприйнятя } \\
\text { музики, формується музичний смак, здатність до оцінювання } \\
\text { йсамооцінювання }\end{array}$ \\
\hline
\end{tabular}

Крім спеціальних здібностей, музично обдаровані люди часто мають суміжні таланти, зокрема літературні, математичні, і вони можуть бути позначені позитивною динамікою взаємовпливу. Існує думка, що попри те, що названі здібності мають різні центри управління в корі головного мозку, вони функціонально пов'язані між собою, зокрема в тому, що стосується оброблення інформації (Таллибулина, 2016, с. 108).

У науковій літературі навіть виникла дискусія щодо так званого «Ефекту Моцарта». Ідеться про майже магічний влив музики Моцарта, результатом якого $€$ покращання просторово-математичних здібностей, підвищення рівня IQ. Наразі немає достатньої доказової бази для наукового підтвердження «Ефекту Моцарта», тим не менше ця тема продовжує викликати жвавий інтерес у дослідників (Campbell, 2001; Chabris, 1999). У той самий час, чимало фахівців не вважають інтелект головною передумовою музичної обдарованості, хоча до супровідних чинників його, напевно, можна віднести. Адже за статисткою рівень інтелекту музично обдарованих дітей перевищує середній (Таллибулина, 2016, с. 97).

Ібука Масару у своїй книзі «Після трьох уже пізно» оповів історію сім'ї, яка залишила дитину в інтернаті на рік і два місяці через необхідність багато працювати. Перебування в інтернаті призвело до відставання дитини в загальному розвиткові. Однак, на цьому тлі дитина у віці 4-5років почала виявляти здібності й інтерес до музики, зокрема це проявилося у грі на скрипці та фортепіано. Здивовані батьки вже потім з'ясували, що в інтернаті не дуже добре опікувалися інтелектуальним розвитком дітей, проте щовечора, перед сном, прокручували платівки 3 колисковими Моцарта і Шуберта (Ибука Мисару, 1991, с. 60-61). 
Наведений вище фрагмент цікавий із кількох точок зору. По-перше, він засвідчує, наскільки важливо для розвитку музичних здібностей чути гарну, якісну музику вже з раннього дитинства. По-друге, певною мірою вказує на те, що музика Моцарта сам по собі не допомагає розвивати загальний інтелект без спеціальних занять і зусиль. По-третє, унаочнює, яку роль може відіграти той самий «щасливий шанс» навіть за не дуже сприятливих обставин.

Завершуючи розгляд проблеми взаємозв'язку інтелектуальних і музичних здібностей, вважаємо доречним навести дотичні міркування Б. М. Тєплова, які поділяємо: «Музика не може дати нових фактичних знань або ідей, але вона може з великою імовірністю поглибити вже наявні знання, зробити їх більш емоційно насиченими (Теплов, 1947, с. 22). Визначним музикантом може бути тільки людина з великим духовним, інтелектуальним і емоційним змістом. Музика - це засіб спілкування між людьми. Щоб говорити музикою потрібно володіти не тільки цією мовою, а й мати, що сказати. Гарний музикант, ким би він не був - композитором, виконавцем, слухачем, - повинен бути людиною великого розуму i великого почуття (Теплов, 1947, с. 34).

Музично обдарована особистість здатна досить швидко, порівняно 3 іншими галузевими обдарованостями, досягати рівня майстра. Надзвичайну сприйнятливість до музики і глибоке ії розуміння обдаровані діти починають виявляти вже на першому-другому роках життя. А провісники музичної обдарованості можуть даватися взнаки навіть у віці немовляти. Так, за висновком Г. Гарднера, двохмісячні малюки вже здатні правильно повторювати тон, гучність і мелодійну канву пісень матері, а в чотири місяці - точно імітувати ритмічну структуру (Гарднер, 2007, с. 160). I якщо статистично нормальні діти у два роки вміють імітувати мелодію, яка щойно прозвучала, у 4 роки вивчити й проспівати пісню і лише в 5 років досить точно виконати пісню, то обдаровані діти здатні досягти точності виконання вже в два роки. Нерідко вони починають мугикати мелодії пісень раніше, аніж навчаться говорити (Winner \& Martino, с. 105).

Музично обдаровані діти дошкільного віку проявляють особливу зацікавленість і навіть захоплення від звуків музики. Вони вирізняються особливою чутливістю до мелодійного звучання і мають гарну музичну пам'ять, здатні підспівувати, проспівувати музичні твори з високою точністю, охоче вправляються в грі на музичних інструментах. Найчастіше йдеться про виконавські здібності, хоча найбільш талановиті беруться за створення власних музичних композицій. Так, Вольфганг Моцарт у п'ятирічному віці вже писав невеликі музичні п'єси, а в шість років самотужки опанував гру на скрипці (Deutsch, 1996).

Прикметно, що надзвичайно обдаровані діти характеризуються здатністю до стрімкого ривка в музичному розвитку в період 5-7 років 
(Таллибулина, 2016, с. 126). І це дає їм гарні шанси на досягнення вершин таланту в майбутньому за умови належного старання й бажання самовдосконалюватися. А от у дітей з менш вираженими здібностями та мотивацією розвиток музичних здібностей сповільнюється або й зовсім припиняється з початком шкільного навчання (Гарднер, 2007, с. 161).

Природні здібності музикальних дітей можуть проявлятися порізному: вони хочуть і прагнуть опановувати гру на різних музичних інструментах, люблять імпровізувати, співати, рухатися під музику. Почасти ці уподобання можуть виглядати як спонтанні, однак, якщо придивитися уважніше, то з великою імовірністю в найближчому оточенні дитини знайдеться хтось, хто залюбив ії у музику, підтримав, навчив. Наразі дослідниця Л. А. Сосняк стверджує, що в усіх видатних піаністів у сім'ї або в колі близьких, знайомих, були особи, які сприяли розвиткові юних талантів змалечку (Sosniak, 1985).

Для Вольфганга Моцарта, наприклад, головним наставником i помічником був батько - Леопольд Моцарт, відомий композитор, скрипач і педагог. Саме він подбав про те, щоб музична практика сина стала щоденною вже з шести років і була успішною.

Утім у ранній спеціалізації музично обдарованих дітей є як переваги, так і певні перестороги. 3 одного боку, більш продуктивно використовується період максимальної сенситивності до занять музикою, подовжується час для розвитку здібностей у тому чи іншому виді музичної діяльності. 3 другого боку, імовірні проблеми, пов'язані 3 втратою перспектив щодо інших видів здібностей, якщо йдеться про мультиобдаровану особистість. Скажімо, дитина має не один музичний хист, а кілька (різні виконавчі стилі, різні музичні інструменти, вокал, ритміка тощо), і до того ж, гарну пам'ять, інтелектуальні, літературні, просторово-рухові здібності, тоді рання і неухильна спеціалізація на якомусь одному напрямі може стати на заваді реалізації інших талантів.

I річ не тільки в браку часу, а й у тому, що фізичні та психологічні ресурси дитини, навіть дуже здібної, $є$ об'єктивно обмеженими. І щоб уникнути перевантажень, вигоряння необхідно враховувати, що діти 5-6 років (а саме в цьому віці найчастіше починають брати уроки музики) $\epsilon$ фізично невитривалими і психологічно вразливими. Наприклад, їхні м’язи ще досить тендітні, щоб довго утримувати в руках скрипку, долоні не достатньо широкі, а пальці не такі вправні, щоб довго грати на піаніно; довільна увага не настільки стійка, щоб годинами сприймати музику на слух. До того ж, підвищена сенситивність до звуків може бути джерелом як позитивних, так і негативних емоцій. Надто голосні, дисгармонічні звуки в особливо чутливих дітей можуть викликати сильний дискомфорт, що межує з фізичним стражданням, а мінорні, тривожні музичні тексти породжувати страх, провокувати депресивні стани (Distin, 2006, с. 205). 
3 огляду на сказане організація музичних занять для обдарованих дітей вимагає врахування не лише специфіки індивідуальних здібностей, а й вікових особливостей. Систематичність і системність навчання безумовно необхідні, але лише тією мірою, якою не завдають шкоди дитячому організму. Слід також зважати на те, що музикальні діти не меншою мірою потребують тиші, аніж перебування в полоні звуків. Серед них є чимало творчих особистостей, інтровертів, які люблять побути на самоті: мріяти, думати про музику, чути й переживати ії внутрішньо. Завдяки внутрішньому слуху вони здатні «чути те, що бачать, і бачити те, що чують» (Campbell, 1989, с. 304; Hallam, 1995).

У зв'язку зі сказаним вище фахівці радять віддавати перевагу ігровим методам при організації занять із музично обдарованими дітьми дошкільного віку (Sosniak, 1990). Надто, коли йдеться про перші кроки дитини в тому чи тому виді діяльності - грі на інструментах, вокалі, сценічному мистецтві тощо. По суті, такий підхід можна схарактеризувати як створення безпечного для здоров'я розвивального середовища, де «живе музична гра». Як наслідок, дитина може досягати навіть більшого, аніж від неї очікують, i значно меншими зусиллями. При цьому чарівна аура дитинства не тільки не затьмарюватиметься, а навпаки, наповнюватиметься яскравими звуками й кольорами, а ключі та ноти ставатимуть кращими друзями вже змалечку. Більш віддалений ефект може полягати в закріпленні за музичною практикою ореолу романтики, зачарування, а також у формуванні стійкої мотивації до самовдосконалення в музиці як професійній діяльності.

Разом із тим, навчання музиці, як і будь-якій іншій справі, не може бути суцільною насолодою, а гедонізм - єдиною мотивацією. Скажімо, почуття задоволення може зробити щасливим музичного фаната, але цього замало для народження музичного генія. Тому з біографій геніальних людей дізнаємося про те, що в дитинстві їх не лише мотивувати, але й спонукали, підштовхували до успіху через невпинну роботу над собою.

Наприклад, для Людвіга Бетховена заняття музикою розпочалися вже в шість років саме за наполягання батька. На думку батька, хлопчик мав навчитися грати на музичних інструментах і заробляти цим на життя як це було заведено в родині. Тренування були щоденними й доволі втомливими, позаяк Людвіг вчився грати на п'яти музичних інструментах одночасно: орган, клавесин, альт, скрипка, флейта (Людвиг ван Бетховен). Так розпочався шлях великого генія.

На прикладах із життя видатних композиторів, музикантів, маестро, оперних і естрадних співаків можливо й потрібно навчати дітей тому, що для досягнення успіху необхідна наполеглива праця. Адже в музиці, як і в спорті, якість виконавської техніки перебуває в прямій залежності від кількості тренувань, а кожна тривала перерва може призвести до втрати вже набутих навичок і необхідності їх поновлювати. Так, досліджуючи ці 
проблеми, Е. Еріксон з'ясував, що за розривом у рівні досягнень у музиці 18-річних студентів стоїть саме різниця в годинах, присвячених музичній практиці. У кращих студентів сумарна кількість тренувальних годин сягала 7,410, тоді ж як у слабших - 5,301 (Ericsson et al., 1993, с. 363-406). Згідно з висновком Дж. Слободи, щоб досягти стандарту гарного виконавцяаматора в музиці, необхідно провести щонайменше 3000 годин практичних занять і тренувань (Sloboda et al., 1996). А якщо йдеться про необхідність досягти стандарту професійного музиканта, потрібні регулярні заняття впродовж тривалого періоду часу загальною кількістю 10000 годин. Навіть, якщо тренуватися щодня по три години, ця підготовка триватиме десять років (Ericsson et al., 1993).

Специфічність музичного таланту полягає в тому, що з одного боку, він вимагає творчості, тонкої чутливості до прекрасного, а з іншого - логіки, змістовності й технічної досконалості відповідно до обраної спеціалізації. Тому в ідеалі мають бути задіяні обидва канали ініціації обдарованої дитині в світі музики: ідеальний - сенситивність, образність, креативність, гра уяви; і практичний - імітація, заучування, тренування, автоматизація дій. Важливо, щоб не тільки вчителі, а й батьки дітей дбали про пошук оптимальної рівноваги між творчістю і рутиною в процесі розвитку юних талантів. Родина може долучитися до цієї справи, створюючи виховне середовище, у якому поціновують мистецтво і поважають пов'язану з ним працю, де звучить якісна музика, доступна музична бібліотека, де поділяють і підтримують інтереси музично обдарованої дитини, супроводжують позитивним підкріпленням кожен крок на шляху до майстерності.

Висновки. Аналіз феномена музичних здібностей дає підстави для висновку про те, що обдаровані діти народжуються вже з генетичними задатками для занять музикою. Порівняно з іншими галузевими обдарованостями музичні здібності мають властивість проявлятися досить рано і можуть бути поміченими навіть у віці немовляти. Надалі вроджені задатки, схильності обдарованої дитини розвиваються в процесі активної взаємодії із зовнішнім середовищем та пов'язаних із музикою видах діяльності.

На становлення й розвиток музичних талантів справляють значний вплив родинні умови, харизматичні вчителі, наставники, які ініціюють, мотивують, підтримують, спонукають, тренують, ведуть до спіху. У процесі педагогічної роботи з музично обдарованими дітьми необхідно враховувати як специфіку індивідуальних здібностей (здатності, уподобання, інтереси), так і вікові особливості - фізіологічні, психологічні. 3 метою оптимізації процесу навчання важливо підтримувати тісні контакти 3 рідними, близькими обдарованої дитини, серед яких досить часто трапляються найперші і значущі вчителі. У роботі з музично обдарованими дітьми дошкільного віку доцільно надавати перевагу ігровим методам, а з дітьми більш старшого віку - віднаходити продуктивну рівновагу між творчими й 
суто технічними, тренувальними видами діяльності. Музикальні діти з мультиобдарованістю потребують особливої уваги й супроводу з точки зору навчальної та професійної орієнтації у світі музики, мистецтва.

\section{ЛІТЕРАТУРА}

Гарднер, Г. (2007). Структура разума: теория множественного интеллекта. М.:, Спб.:, К.: Вильямс (Gardner, Н. (2007). The frames of mind: The theory of multiple intelligences. M.:, SPb.:, K.: Viliams).

Ибука Масару (1991). После трех уже поздно. М.: Знание (Ibuka Masaru (1991). After three it's too late. M.: Knowledge).

Людвиг ван Бетховен. Биография (Ludwig van Beethoven. Biography). Retrieved from: https://24smi.org/celebrity/4475-liudvig-van-betkhoven.html. (28.05.2019).

Таллибулина, М. Т. (2016). Психологические исследования одаренности. М.; Берлин: Директ-Медиа (Tallibulina, М. Т. (2016). Psychological research on giftedness. М.; Berlin: Direct Media).

Теплов, Б. М. (1947). Психология музыкальных способностей. М.-Л.: АПН РСФСР (Teplov, B.M . (1947). Psychology of musical ability. M .-L.: APS of the RSFSR).

Campbell, P. S. (1989). Dalcroze reconstructed: an application of music learning theory to the principles of Jacques Dalcroze. In D. L.Walters \& C. C. Taggart (Eds.), Readings in M usic Learning Theory, pp. 301-315. Chicago, III: GIA Publishers.

Campbell, D. (2001). The Mozart Effect: Tapping the power of music to heal the Body, strengthen the mind, and unlock creative spirit. London: Quill.

Chabris, C. F. (1999). Prelude or requiem for the "M ozart effect"? Nature, 400, 826-827.

Deutsch, O. E. (1996). M ozart: A documentary biography. London: Adam \& Charle Black.

Distin, K. (2006). Gifted Children: A Guide for Parents and Professionals. London.

Ericsson, K. A., Krampe, R. T., \& Tesch-Römer, C. (1993). The role of deliberate practice in the acquisition of expert performance. Psychological Review, 100 (3), 363-406.

Hallam, S. (1995). Professional musicians' approaches to the learning and interpretation of music. Psychology of Music, 23, 111-128.

Haroutounian, J. (2000). Perspectives of musical talent: a study of identification criteria and procedures. High Ability Studies, 11 (2), 137-160.

Parncutt, R. \& McPherson, G. (Eds.) (2002). The science and Psychology of Music Performance: Creative Strategies for Teaching and Learning. Oxford: Oxford University Press.

Shuter-Dyson, R. (1982). M usical ability, In Deutsch (Ed.), The psychology of music, pp. 391408. San Diego: CA: Academic Press.

Sloboda, J. A., Davidson, J. W., Howe, M. J. A., \& Moore, D. G. (1996). The role of practice in the development of performingmusicians. British Journal of Psychology, 87, 399-412.

Sosniak, L. A. (1985). Learning to be a concert pianist. In B. S. Bloom (Ed.), Developing talent in young people, pp. 19-57. New York: Ballantine Books.

Sosniak, L. A. (1990). The tortoise, the hare, and the development of talent. In M. J. Howe (Ed.), Encouraging the development of exceptional skills and talents, pp.149-64. Leicester, UK.: British Psychological Society.

Winner, E. \& Martino, G. (2000). Giftedness in non-academic domains. The case of the visual arts and music. In K. A. Heller, F. J. Mönks, R. J. Sternberg, R. E. Subotnik (Eds.), International handbook of giftedness and talent ( $2^{\text {nd }}$ ed.), pp. 95-110. Pergamon, Oxford.

Winner, E. (1996). Gifted Children: M yths and Realities. New York: BasicBooks. 


\section{PEЗЮME}

Лавриченко Наталия. Развивать музыкальную одаренность.

Феномен музыкальной одаренности рассмотрен в совокупности генетических предпосылок, основных факторов развития, структурных составляющих и особенностей реализации в реальной жизненной практике. Проанализованы специфические признаки и характеристики музыкально одаренной личности, в частности в контексте других видов одаренности, мультиодаренности.

Ключевые слова: одаренный ребенок, музыкальные способности, обучение, развитие.

\section{SUMMARY}

Lamychendko Nataliia. To Develop M usical Giftedness.

The phenomenon of musical giftedness is considered in the set of genetic preconditions, main factors of development, structural components and peculiarities of realizing in life practice. The specific features and characteristics of a musically gifted personality are analyzed, in particular in the context of the other types of giftedness, multigiftedness.

The peculiarities of developing musically gifted children at certain stages of their growing adult and the problems that may arise in this connection - physiological, psychological, educational, as well as pedagogical ways of their solving are revealed.

The aim - to analyze the nature and dynamics of developing musical giftedness, to reveal the peculiarities of pedagogical work with musically gifted children.

The following scientific methods have been applied for realising the purpose: analysis, synthesis, generalization, concretization, systematization.

It is concluded that gifted children are born with genetic inclinations for playing music. Compared to other types of giftedness, musical abilities usually show up early enough and can be seen even at infancy. Later innate inclinations of the gifted child develop in the process of active interaction with the environment and music-related activities.

Family conditions, charismatic teachers, and mentors who initiate, motivate, support, encourage, train, and lead influence significantly formation and development of musical talents. In the course of pedagogical work with musically gifted children it is necessary to take into account both the specifics of individual abilities (preferences, interests) and age characteristics - physiological, psychological. In order to optimize the learning process, it is important to maintain close contact with relatives of the gifted child, among whom are often the first and most important teachers. When working with musically gifted preschool children, it is advisable to give preference to game methods, and with older children - to find a productive balance between creative and purely technical, training activities.

Key words gifted child, musical abilities, educating, developing. 